\title{
FAKTOR-FAKTOR YANG MEMPENGARUHI PENERIMAAN HASIL PADI (Oryza sativa L.) DI KABUPATEN INDRAMAYU
}

\author{
Wiwik Ambarsari ${ }^{1)}$, Vitus Dwi Yunianto Budi Ismadi ${ }^{2)}$, Agus Setiadi ${ }^{3)}$ \\ ${ }^{1)}$ Program Studi Agribisnis Fakultas Pertanian Universitas Wiralodra \\ ${ }^{2)} 3$ Fakultas Peternakan dan Pertanian Universitas Diponegoro \\ Email : wiwikambarsari@yahoo.co.id
}

\begin{abstract}
ABSTRAK
Penelitian ini bertujuan untuk menentukan faktor-faktor yang mempengaruhi penerimaan hasil padi pada tingkat petani di Kabupaten Indramayu. Penelitian ini dilakukan sejak bulan Februari sampai Agustus 2014 di Kecamatan Sliyeg, Lelea, dan Gabuswetan, Kabupaten Indramayu. Penelitian ini dilakukan dengan pendekatan survei, menggunakan analisis deskriptif kuantitatif. Pengambilan sampel petani padi dilakukan secara multistage purposive sampling berjumlah 120 orang pada periode 2012/2013. Hasil penelitian ini menunjukkan bahwa faktor harga benih, harga pupuk, harga pestisida, upah tenaga kerja, dan sewa lahan secara serempak berpengaruh nyata terhadap penerimaan hasil padi di tingkat petani pada musim tanam pertama dan kedua; faktor harga benih, upah tenaga kerja, dan sewa lahan secara parsial berpengaruh nyata pada penerimaan hasil padi di tingkat petani pada musim tanam pertama dan faktor-faktor dari harga benih, harga pestisida, dan upah tenaga kerja secara parsial berpengaruh nyata terhadap penerimaan hasil padi di tingkat petani pada musim tanam kedua.
\end{abstract}

Kata kunci : faktor-faktor produksi, hasil padi

\begin{abstract}
This research aims to determine the factors that affect the acceptability of rice yields at the farm level in Indramayu Regency. The research was conducted from February to August 2014 in Sliyeg, Lelea, Gabuswetan Districts, Indramayu Regency. This research was done through a survey approach, using descriptive quantitative analysis. The sampling was done by multistage purposive sampling to 120 rice farmers on periode 2012/2013. The analysis methods that was used multiple linear regression method with SPSS 19 (Statistical Package For Social Science. 19). The results of this research were the price factors of seeds, fertilizers, pesticides, labor costs, and land rent gave significant effect to the acceptance of rice yields at the farm level in the first and second growing seasons; the price factors of seeds, labor costs, and land rents gave partially significant effect to the acceptance of rice yields at the farm level in the first growing season; and the price factors of seeds, pesticides, and labor costs gave partially significant effect to the acceptance of rice yields at the farm level in the second growing season.
\end{abstract}

Keywords : factors production, rice yield

\section{PENDAHULUAN}

Penerimaan hasil padi (Oryza sativa L.) sangat dipengaruhi oleh faktor-faktor produksi, seperti lahan, benih, pupuk, pestisida, tenaga kerja, dan lain-lain. Faktor-faktor produksi padi ini menjadi faktor pembatas sehingga dapat menjadi permasalahan utama pada penerimaan hasil padi. Soekartawi, dkk. (1986) menjelasakan bahwa produksi usahatani sangat dipengaruhi oleh beberapa faktor, yang ditulis dalam fungsi produksi, yaitu :

$\mathrm{Y}=\mathrm{f}\left(\mathrm{X}_{1}, \mathrm{X}_{2}, \mathrm{X}_{3}, \ldots . \mathrm{X}_{\mathrm{n}}\right)$

Dimana $\mathrm{Y}$ (tingkat produksi atau output yang dihasilkan), $\mathrm{f}$ (bentuk hubungan yang mentrasformasikan faktor-faktor produksi dalam hasil produksi) dan $\mathrm{X}_{\mathrm{n}}$ (faktor-faktor ke-n yang digunakan dalam proses produksi).

Faktor-faktor yang digunakan dalam proses produksi tersebut adalah lahan, tenaga kerja, modal, pupuk, pestisida, benih, dan teknologi. Pertama, lahan merupakan faktor penentu dalam penerimaan hasil komoditas pertanian, semakin luas lahan yang diusahakan maka semakin besar jumlah hasil yang diperoleh lahan tersebut, selain itu lahan dilihat dari tingkat kesuburan lahan dan jenis penggunaan lahan (tanah sawah, tegalan, kebun dan lainnya) serta topografi (tanah dataran tinggi, rendah, atau pantai). 
Kedua, tenaga kerja dalam hal ini adalah petani padi yang menjadi faktor utama dan harus diperhitungkan dalam proses produksi komoditas pertanian. Semakin berkualitas tenaga kerja maka semakin mudah menerima inovasi baru dalam hal menggunakan teknologi untuk memperoleh hasil yagn bagus sehingga nilai jual tinggi. Meskipun berkembang sistem upah borongan, namun ukuran tenaga kerja dinyatakan dalam harian orang kerja (HOK), sedangkan dalam analisis ketenagakerjaan diperlukan standarisasi tenaga kerja yang bisa disebut dengan hari kerja setara pria (HKSP).

Ketiga, setiap kegiatan membutuhkan modal dalam proses produksi komoditas pertanian, yang terdiri dari modal tetap (fixed cost) yang terdiri atas tanah, bangunan, mesin, dan peralatan bertani serta modal tidak tetap (variabel cost) seperti benih, pupuk, pestisida, dan upah tenaga kerja. Keempat, dalam usahatani komoditas pertanian diperlukan pupuk dalam bentuk organik atau pupuk alam maupun pupuk anorganik. Pupuk organik berasal dari bahan organik seperti pupuk kandang, pupuk hijau, kompos, guano. Pupuk anorganik berasal dari bahan kimia buatan yang dihasilkan oleh pabrik atau industri, misalnya pupuk Urea, $\mathrm{KCl}$, TSP.

Kelima, pestisida merupakan pembasmi hama dan penyakit tanaman, berupa racun yang mengandung zat-zat aktif dibutuhkan pada saat pemeliharaan tanaman. Keenam, benih merupakan cikal bakal tanaman apakah tumbuh baik atau tidak. Benih unggul yang berkualitas biasanya memiliki kelebihan secara genetis dan fisiologis sehingga tanaman yang akan memiliki kuantitas dan kualitas yang baik dibandingkan tanaman lainnya. Ketujuh, teknologi dapat meningkatkan hasil. Dengan teknologi, tanaman dapat ditanam tiga kali atau lebih dalam setahun.

Perkembangan penanaman padi dari tahun ke tahun di Kabupaten Indramayu mengalami penurunan, terutama luas panen padi, sehingga dapat mengakibatkan penurunan hasil produksi padi. Salah satu penyebab yang teridentifikasi adalah terjadi karena adanya konversi lahan pertanian (terutama sawah) kepada peruntukan lahan non pertanian, seperti berdirinya bangunan untuk perumahan atau pemukiman maupun industri, infrastruktur pendukung, dan perdagangan. Suherman (2013) menyebutkan bahwa Kabupaten Indramayu mengalami konversi lahan sawah beririgasi ke non pertanian sebesar 0,12 persen per tahun dari total lahan sawah 116.039 hektar dan cenderung meningkat setiap tahunnya karena sejalan dengan perkembangan penduduk dan kebutuhan lahan serta perkembangan perekonomian suatu wilayah.

Permasalahan produksi padi di

Kabupaten Indramayu selain penurunan luas panen, yaitu: (1) tingkat kehilangan hasil akibat pengolahan pasca panen masih terlalu tinggi, (2) masih tingginya serangan organisme penyakit tanaman utama, (3) bencana alam kebanjiran dan kekeringan yang cukup luas, (4) permodalan yang dimiliki petani masih rendah, (5) teknologi spesifik belum diterapkan secara lengkap dan berkelanjutan, dan (6) marketable surplus yang masih belum tertangani secara nyata sehingga mempengaruhi cara budidaya padi (Dinas Pertanian dan Peternakan Kabupaten Indramayu Tahun 2012). Upaya yang telah dilakukan oleh pemerintah untuk mengatasi permasalahan usahatani padi adalah melalui program Kementerian Pertanian, yaitu gema revitalisasi dan ketahanan pangan. Gema revitalisasi, yaitu : (1) lahan, (2) pembenihan dan perbibitan, (3) infrastruktur dan sarana, (4) sumber daya manusia, (5) pembiayaan, (6) kelembagaan, dan (7) teknologi dan industri hilir. Program ketahanan pangan selama tahun 2010-2014 bertujuan mengatasi permasalahan yang ada, diantaranya melalui : (1) penerapan Sekolah Lapang Pengelolaan Tanaman Terpadu (SLPTT), (2) mengantisipasi pengamanan dalam peningkatan Organisme Pengganggu Tanaman (OPT), (3) dampak perubahan iklim (DPI) melalui pengawalan yang ketat, (4) pemberdayaan petugas di lapangan, (5) koordinasi dengan instansi terkait, (6) gerakan pengendalian, (7) peningkatan kewaspadaan, (8) penyiapan sarana dan prasarana, (9) bantuan benih melalui Bantuan Langsung Benih Unggul (BLBU) dan (10) bantuan pupuk melalui Bantuan Langsung Pupuk (BLP). Berdasarkan penjelasan tersebut, maka penelitian ini bertujuan untuk menganalisis faktor-faktor yang mempengaruhi penerimaan hasil padi di tingkat petani di Kabupaten Indramayu.

\section{METODE PENELITIAN}

Penelitian ini adalah penelitian deskriptif kuantitatif dengan metode pendekatan survey (Nazir, 1983). Lokasi penelitian di Kecamatan Sliyeg, Kecamatan Lelea, dan Kecamatan Gabuswetan Provinsi Jawa Barat. Pelaksanaan penelitian ini dilaksanakan pada bulan Februari 
s/d Agustus 2014. Teknik pengambilan sampel adalah multistage purposive sampling (pertimbangan) sebanyak 120 responden petani (Soekartawi, 1986). Analisis yang digunakan untuk penentuan faktor-faktor yang mempengaruhi penerimaan hasil padi di tingkat petani dapat diperoleh dengan analisis regresi linier berganda (multiple lenear regression) melalui program SPSS 19 (Statistical Package For Social Science 19), yang terdiri dari uji koefisien korelasi, uji koefisien determinasi, uji F, dan uji t. Model persamaannya menurut Gomez \& Gomez (1995) dan Nazir (1983), yang digunakan adalah :

$Y=a+b_{1} X_{1}+b_{2} X_{2}+b_{3} X_{3}+b_{4} X_{4}+b_{5} X_{5}+e$

Dimana: Y (Penerimaan usahatani padi di tingkat petani (Rp)), a (Konstanta), $b_{1} s / d b_{5}$ (Koefisien Regresi untuk variabel 1, 2, 3, 4, dan 5), $X_{1}$ (Variabel harga benih (Rp)), $X_{2}$ (Variabel harga pupuk (Rp)), $X_{3}$ (Variabel harga pestisida (Rp)), $\mathrm{X}_{4}$ (Variabel upah tenaga kerja (Rp)), $\mathrm{X}_{5}$ (Variabel sewa lahan $(\mathrm{Rp})$ ) dan e (Error, faktor pengganggu).

\section{Uji Koefisien korelasi ( $\mathbf{r}$ atau $\mathbf{R}$ )}

Hubungan biaya variabel bebas $\left(\mathrm{X}_{\mathrm{i}}\right)$, yaitu harga benih $\left(\mathrm{X}_{1}\right)$, harga pupuk $\left(\mathrm{X}_{2}\right)$, harga pestisida $\left(\mathrm{X}_{3}\right)$, upah tenaga kerja $\left(\mathrm{X}_{4}\right)$, dan sewa lahan $\left(\mathrm{X}_{5}\right)$ terhadap variabel terikat $(\mathrm{Y})$, yaitu penerimaan usahatani padi di tingkat petani, digunakan uji korelasi. Nilai korelasi (r) sebesar $-1<\mathrm{r}<1$ dengan persamaan :

$$
\mathrm{r}=\frac{\sum x y}{\sqrt{\sum x^{2} \sum y^{2}}}
$$

Tabel 1. Kriteria Koefisien Korelasi ( $\mathrm{r}$ atau R)

\begin{tabular}{ll}
\hline Koefisien Korelasi & Kriteria \\
\hline $0,000<\mathrm{r}<0,200$ & Korelasi sangat rendah \\
$0,200<\mathrm{r}<0,400$ & Korelasi rendah \\
$0,400<\mathrm{r}<0,600$ & Korelasi agak rendah \\
$0,600<\mathrm{r}<0,800$ & Korelasi cukup \\
$0,800<\mathrm{r}<1,000$ & Korelasi tinggi \\
\hline
\end{tabular}

Sumber : Arikunto, 2006.

\section{Uji Koefisien determinasi ( $\mathbf{r}^{2}$ atau $\mathbf{R}$ square)}

Besarnya pengaruh variabel bebas $\left(\mathrm{X}_{\mathrm{i}}\right)$, yaitu harga benih $\left(\mathrm{X}_{1}\right)$, harga pupuk $\left(\mathrm{X}_{2}\right)$, harga pestisida $\left(\mathrm{X}_{3}\right)$, upah tenaga kerja $\left(\mathrm{X}_{4}\right)$, dan sewa lahan $\left(\mathrm{X}_{5}\right)$ terhadap variabel terikat $(\mathrm{Y})$, yaitu penerimaan usahatani padi di tingkat petani, digunakan uji koefisien determinasi atau $\mathrm{R}$ square $\left(\mathrm{R}^{2}\right)$, dinyatakan dalam persen nilai $\mathrm{R}^{2}$ sebesar $0<\mathrm{R}^{2}<1$.
Tabel 2. Kriteria Koefisien Determinasi $\left(r^{2}\right.$ atau $\left.R^{2}\right)$

\begin{tabular}{ll} 
Koefisien & \multicolumn{1}{c}{ Kriteria } \\
Determinasi & \\
\hline $\mathrm{R}^{2}<0,50$ & Determinasi tidak kuat \\
$0,50<\mathrm{R}^{2}<0,59$ & Determinasi cukup kuat \\
$0,60<\mathrm{R}^{2}<0,79$ & Determinasi kuat \\
$0,80<\mathrm{R}^{2}<1,00$ & Determinasi sangat kuat
\end{tabular}

Sumber : Supranto, 1995.

Uji F

Pengaruh variabel bebas $\left(\mathrm{X}_{\mathrm{i}}\right)$, yaitu harga benih $\left(\mathrm{X}_{1}\right)$, harga pupuk $\left(\mathrm{X}_{2}\right)$, harga pestisida $\left(\mathrm{X}_{3}\right)$, upah tenaga kerja $\left(\mathrm{X}_{4}\right)$, dan sewa lahan $\left(\mathrm{X}_{5}\right)$ terhadap variabel terikat $(\mathrm{Y})$, yaitu penerimaan usahatani padi di tingkat petani secara simultan dapat diketahui dengan menggunakan uji $\mathrm{F}$ (F-test) dengan kriteria pada signifikan $\mathrm{F}$ taraf $5 \%$, yaitu :

$\mathrm{F}_{\text {hit }}=\frac{\sum \text { Kuadrat regresi }}{\sum \text { Kuadrat residual }}$

Hipotesis statistiknya adalah :

$$
\begin{aligned}
\mathrm{H}_{0} \quad: \mathrm{b}_{1}=\mathrm{b}_{2}=\mathrm{b}_{3}=\mathrm{b}_{4}=\mathrm{b}_{5}=0 \text {, tidak } \\
\text { ada pengaruh variabel bebas }\left(\mathrm{X}_{\mathrm{i}}\right) \\
\text { secara simultan terhadap variabel } \\
\text { terikat }(\mathrm{Y}) \\
\mathrm{H}_{1}:: \mathrm{b}_{1} \neq \mathrm{b}_{2} \neq \mathrm{b}_{3} \neq \mathrm{b}_{4} \neq \mathrm{b}_{5} \neq 0 \text {, terdapat } \\
\text { pengaruh variabel bebas }\left(\mathrm{X}_{\mathrm{i}}\right) \text { secara } \\
\text { simultan terhadap variabel terikat }(\mathrm{Y})
\end{aligned}
$$

\section{Uji t}

Uji t adalah untuk mengetahui pengaruh variabel bebas $\left(\mathrm{X}_{\mathrm{i}}\right)$, yaitu harga benih $\left(\mathrm{X}_{1}\right)$, harga pupuk $\left(\mathrm{X}_{2}\right)$, harga pestisida $\left(\mathrm{X}_{3}\right)$, upah tenaga kerja $\left(\mathrm{X}_{4}\right)$, dan sewa lahan $\left(\mathrm{X}_{5}\right)$ terhadap variabel terikat $(\mathrm{Y})$, yaitu penerimaan usahatani padi di tingkat petani secara individu (parsial), dengan syarat bahwa t hitung $>\mathrm{t}$ tabel dan jika nilai signifikan $\mathrm{t} \leq 0,05$ pada taraf $5 \%$.

\section{HASIL DAN PEMBAHASAN}

\section{Analisis Regresi Linier Berganda}

Hasil pendugaaan parameter penelitian ini dari operasional analisis regresi linier berganda dengan program SPSS 19 (Statistical Package For Social Science) sebagaimana tersaji pada Tabel 3.

Uji Koefisien Korelasi ( $\mathbf{r}$ atau R). Hasil uji koefisien korelasi (r) pada Tabel 3 di kolom person correlation, yaitu harga benih $\left(\mathrm{X}_{1}\right)$ berhubungan positif dengan kriteria cukup pada musim tanam pertama sebesar 0,744 dan musim tanam kedua sebesar 0,760 terhadap penerimaan usahatani padi di tingkat petani $(\mathrm{Y})$. 
Harga pupuk $\left(\mathrm{X}_{2}\right)$ berhubungan positif dengan kriteria cukup pada musim tanam pertama sebesar 0,744 dan musim tanam kedua sebesar 0,747 terhadap penerimaan usahatani padi di tingkat petani (Y).

Harga pestisida $\left(\mathrm{X}_{3}\right)$ berhubungan positif dengan kriteria cukup pada musim tanam pertama sebesar 0,740 dan musim tanam kedua sebesar 0,750 terhadap penerimaan usahatani padi di tingkat petani $(\mathrm{Y})$. Upah tenaga kerja $\left(\mathrm{X}_{4}\right)$ berhubungan positif dengan kriteria tinggi pada musim tanam pertama sebesar 0,924 dan musim tanam kedua sebesar 0,852 terhadap penerimaan usahatani padi di tingkat petani (Y). Sewa lahan $\left(\mathrm{X}_{5}\right)$ berhubungan positif dengan kriteria cukup pada musim tanam pertama sebesar 0,785 dan musim tanam kedua sebesar 0,791 terhadap penerimaan usahatani padi petani (Y).

Hasil uji koefisien korelasi secara parsial menunjukkan bahwa hubungan yang paling positif dengan kriteria tinggi adalah upah tenaga kerja $\left(\mathrm{X}_{4}\right)$ pada musim tanam pertama dan musim tanam kedua, masing-masing sebesar 0,924 dan 0,852 terhadap penerimaan usahatani padi di tingkat petani (Y). Uji koefisien korelasi (R) secara multiple (keseluruhan) menunjukkan hubungan yang positif dengan kriteria tinggi antara variabel bebas $\left(\mathrm{X}_{\mathrm{i}}\right)$, yaitu harga benih $\left(\mathrm{X}_{1}\right)$, harga pupuk $\left(\mathrm{X}_{2}\right)$, harga pestisida $\left(\mathrm{X}_{3}\right)$, upah tenaga kerja $\left(\mathrm{X}_{4}\right)$, dan sewa lahan $\left(\mathrm{X}_{5}\right)$ terhadap variabel tidak bebas $(\mathrm{Y})$, yaitu penerimaan usahatani padi di tingkat petani pada musim tanam pertama sebesar 0,977 dan musim tanam kedua sebesar 0,896.

Uji Determinasi ( $r^{2}$ atau R Square). Uji determinasi $\left(\mathrm{R}^{2}\right)$ digunakan untuk mengetahui besarnya pengaruh variabel bebas $\left(\mathrm{X}_{\mathrm{i}}\right)$, yaitu harga benih $\left(\mathrm{X}_{1}\right)$, harga pupuk $\left(\mathrm{X}_{2}\right)$, harga pestisida $\left(\mathrm{X}_{3}\right)$, upah tenaga kerja $\left(\mathrm{X}_{4}\right)$, dan sewa lahan $\left(\mathrm{X}_{5}\right)$ menentukan besarnya persentase variasi variabel tidak bebas (Y), yaitu penerimaan usahatani padi di tingkat petani pada musim tanam pertama dan musim tanam kedua.

Tabel 3 menunjukan bahwa nilai koefisien determinasi $\left(\mathrm{R}^{2}\right)=0,955$ pada musim tanam pertama, artinya 95,50 persen variasi penerimaan usahatani padi di tingkat petani (Y) ditentukan atau dapat dijelaskan oleh variasi variabel bebasnya $\left(X_{i}\right)$, yaitu harga benih $\left(X_{1}\right)$, harga pupuk $\left(\mathrm{X}_{2}\right)$, harga pestisida $\left(\mathrm{X}_{3}\right)$, upah tenaga kerja $\left(\mathrm{X}_{4}\right)$, dan sewa lahan $\left(\mathrm{X}_{5}\right)$ dan sisanya sebesar 5,50 persen dapat dijelaskan oleh variabel lain yang tidak dimasukkan ke dalam model ini, misalnya variabel pajak, pemeliharaan, modal sosial dan lain-lain.
Pada musim tanam kedua bahwa nilai koefisien determinasi $\left(\mathrm{R}^{2}\right)=0,803$, artinya 80,30 persen variasi penerimaan usahatani padi di tingkat petani ( $\mathrm{Y}$ ) ditentukan oleh variasi variabel bebasnya $\left(X_{i}\right)$, yaitu harga benih $\left(X_{1}\right)$, harga pupuk $\left(\mathrm{X}_{2}\right)$, harga pestisida $\left(\mathrm{X}_{3}\right)$, upah tenaga kerja $\left(\mathrm{X}_{4}\right)$, dan sewa lahan $\left(\mathrm{X}_{5}\right)$ dan sisanya sebesar 9,70 persen dijelaskan oleh variabel lain yang tidak dimasukkan ke dalam model ini, misalnya variabel pajak, pemeliharaan, dan lain-lain.

\section{Uji F}

Uji $\mathrm{F}$ digunakan untuk mengetahui variabel bebas $\left(\mathrm{X}_{\mathrm{i}}\right)$, yaitu harga benih $\left(\mathrm{X}_{1}\right)$, harga pupuk $\left(\mathrm{X}_{2}\right)$, harga pestisida $\left(\mathrm{X}_{3}\right)$, upah tenaga kerja $\left(\mathrm{X}_{4}\right)$, dan sewa lahan $\left(\mathrm{X}_{5}\right)$ secara serempak (simultan) berpengaruh terhadap variabel tidak bebas (Y), yaitu penerimaan usahatani padi di tingkat petani pada musim tanam pertama dan musim tanam kedua.

Tabel 3 menunjukkan bahwa hasil perhitungan uji $\mathrm{F}$ pada musim tanam pertama dengan nilai $\mathrm{F}$ hitung $=482,689 \geq \mathrm{F}$ tabel $=2,30$ atau nilai significant $\mathrm{F}$ hitung $=0,000 \leq 0,05$ pada tingkat kepercayaan $95 \%(\alpha=0,05)$, maka kesimpulan statistik menyatakan bahwa hasil pengujian adalah siqnificant, $\mathrm{H}_{0}$ ditolak dan $\mathrm{H}_{1}$ diterima. Hal ini berartinya bahwa variabel bebas $\left(\mathrm{X}_{\mathrm{i}}\right)$, yaitu harga benih $\left(\mathrm{X}_{1}\right)$, harga pupuk $\left(\mathrm{X}_{2}\right)$, harga pestisida $\left(X_{3}\right)$, upah tenaga kerja $\left(X_{4}\right)$, dan sewa lahan $\left(\mathrm{X}_{5}\right)$ secara serempak (simultan) berpengaruh terhadap variabel tidak bebas $(\mathrm{Y})$, yaitu penerimaan usahatani padi di tingkat petani pada musim tanam pertama pada tingkat kepercayaan $95 \%(\alpha=0,05)$.

Tabel 3 menunjukkan bahwa hasil perhitungan uji $\mathrm{F}$ pada musim tanam kedua dengan nilai $\mathrm{F}$ hitung $=93,071 \geq \mathrm{F}$ tabel $=2,30$ atau nilai significant $\mathrm{F}$ hitung $=0,000 \leq 0,05$ pada tingkat kepercayaan $95 \%(\alpha=0,05)$, maka kesimpulan statistik menyatakan bahwa hasil pengujian adalah siqnificant, $\mathrm{H}_{0}$ ditolak dan $\mathrm{H}_{1}$ diterima. Hal ini berartinya bahwa variabel bebas $\left(\mathrm{X}_{\mathrm{i}}\right)$, yaitu harga benih $\left(\mathrm{X}_{1}\right)$, harga pupuk $\left(X_{2}\right)$, harga pestisida $\left(X_{3}\right)$, upah tenaga kerja $\left(\mathrm{X}_{4}\right)$, dan sewa lahan $\left(\mathrm{X}_{5}\right)$ secara serempak ( simultan) berpengaruh nyata terhadap variabel tidak bebas (Y), yaitu penerimaan usahatani padi di tingkat petani pada musim tanam kedua pada tingkat kepercayaan $95 \%(\alpha=0,05)$. Hasil ini sesuai dengan pernyataan bahwa produksi tanaman ini sangat dipengaruhi oleh faktorfaktor lahan, tenaga kerja, pupuk, pestisida, dan teknologi (Soekartawi, dkk. 1986). 
Tabel 3. Hasil Pendugaan Parameter Analisis Regresi Linier Berganda Antara Variabel Bebas $\left(\mathrm{X}_{\mathrm{i}}\right)$ Terhadap Variabel Tidak Bebas (Y) Pada Musim Tanam Pertama (MT-1) dan Musim Tanam Kedua (MT-2)

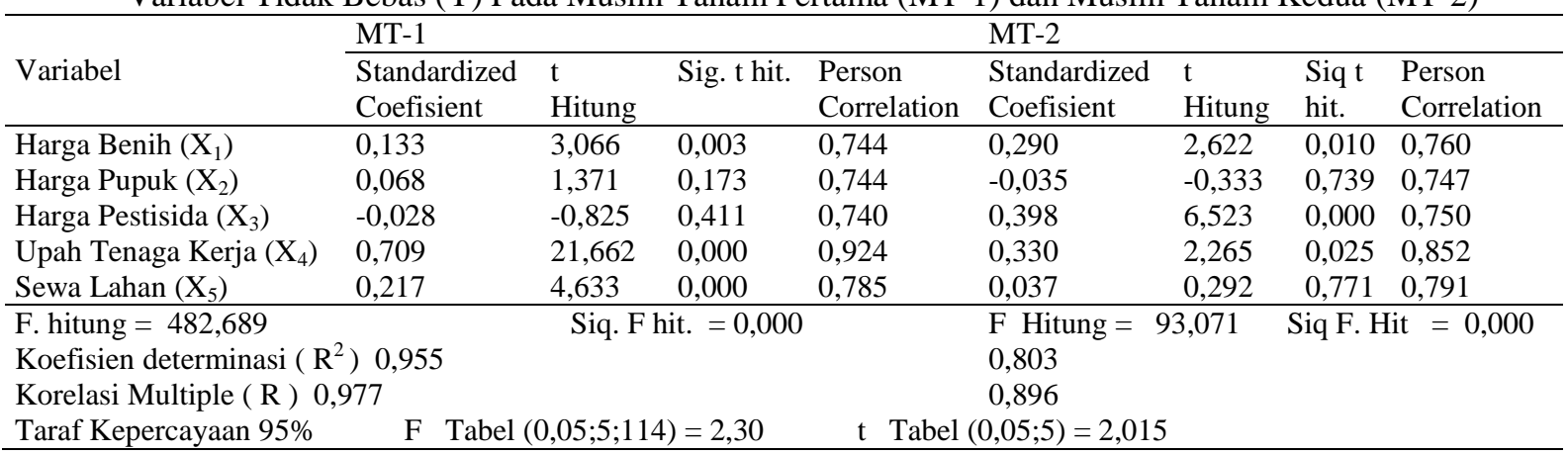

Sumber : Analisis Data Primer Tahun 2014

\section{Uji t}

Hasil uji t pada Tabel 3 menunjukkan bahwa persamaan model regresi dari fungsi penerimaan usahatani padi di tingkat petani pada musim tanam pertama dan musim tanam kedua di daerah penelitian secara umum dapat ditulis sebagai berikut: (1) Persamaan Model Regresi Pada Musim Tanam Pertama :

$\mathrm{Y}=0,133 \mathrm{X}_{1}+0,068 \mathrm{X}_{2}-0,028 \mathrm{X}_{3}+$ $0,709 \mathrm{X}_{4}+0,217 \mathrm{X}_{5}+\mathrm{e}$

Persamaan Model Regresi Pada Musim Tanam Kedua :

$\mathrm{Y}=0,290 \mathrm{X}_{1}-0,035 \mathrm{X}_{2}+0,398 \mathrm{X}_{3}+$ $0,330 \mathrm{X}_{4}+0,037 \mathrm{X}_{5}+\mathrm{e}$

Hasil uji $t$ dari variabel bebas $\left(\mathrm{X}_{\mathrm{i}}\right)$, yaitu harga benih $\left(\mathrm{X}_{1}\right)$, harga pupuk $\left(\mathrm{X}_{2}\right)$, harga pestisida $\left(\mathrm{X}_{3}\right)$, upah tenaga kerja $\left(\mathrm{X}_{4}\right)$, dan sewa lahan $\left(\mathrm{X}_{5}\right)$ secara individu (parsial) berpengaruh nyata atau tidak berpengaruh nyata terhadap variabel tidak bebas (Y), yaitu penerimaan usahatani padi di tingkat petani pada musim tanam pertama dan musim tanam kedua pada Tabel 3, dijelaskan sebagai berikut:

\section{Pengaruh Harga Benih}

Hasil perhitungan uji t pada harga benih $\left(\mathrm{X}_{1}\right)$ terhadap penerimaan usahatani padi di tingkat petani $(\mathrm{Y})$ pada musim tanam pertama diperoleh bahwa nilai $t$ hitung $=3,066 \geq t$ tabel $=2,015$ atau nilai significant $\mathrm{t}$ hitung $=0,003 \leq$ 0,05 dengan tingkat kepercayaan $95 \%(\alpha=$ $0,05)$ menunjukkan siqnificant, maka $\mathrm{H}_{0}$ ditolak dan $\mathrm{H}_{1}$ diterima. Hal ini berarti bahwa variabel harga benih $\left(\mathrm{X}_{1}\right)$ secara individu (parsial) berpengaruh nyata terhadap penerimaan usahatani padi di tingkat petani (Y) dengan tingkat kepercayaan $95 \%$ pada musim tanam pertama. Musim tanam kedua menunjukkan bahwa nilai t hitung pada harga benih $\left(\mathrm{X}_{1}\right)$ terhadap penerimaan usahatani padi di tingkat petani (Y) sebesar 2,66 $\geq \mathrm{t}$ tabel $=2,015$ atau nilai significant $\mathrm{t}$ hitung $=0,010 \leq 0,05$ dengan tingkat kepercayaan $95 \%(\alpha=0,05)$ adalah siqnificant, maka $\mathrm{H}_{0}$ ditolak dan $\mathrm{H}_{1}$ diterima. Hal ini berarti bahwa variabel harga benih $\left(\mathrm{X}_{1}\right)$ secara individu (parsial) berpengaruh nyata terhadap penerimaan usahatani padi di tingkat petani (Y) dengan tingkat kepercayaan 95\% pada musim tanam kedua.

Nilai koefisien regresi sebesar 0,133 pada musim tanam pertama yang artinya adalah penambahan harga benih 1 (satu) persen maka penerimaan usahatani (Y) akan meningkat sebesar 0,133. Pada musim tanam kedua bahwa nilai koefisien regresi sebesar 0,290, yang artinya penambahan harga benih $\left(\mathrm{X}_{1}\right)$ sebesar 1 (satu) persen maka penerimaan usahatani (Y) akan meningkat sebesar 0,290 persen dengan anggapan bahwa faktor penerimaan lainnya tetap (variabel bebas lainnya tetap).

Responden petani padi menggunakan benih unggul berlabel Ciherang sebanyak 97 orang $(80,83 \%)$, Mekongga sebanyak 5 orang $(4,17 \%)$, dan yang lainnya berjumlah 18 orang (15\%). Kondisi ini mencerminkan bahwa penggunaan benih unggul sekitar $85 \%$ yang artinya petani sudah menyadari betapa pentingnya benih sebagai modal utama untuk memperoleh hasil. Soekartawi, dkk. (1986) menyatakan bahwa penggunaan benih sebagai input produksi merupakan cikal bakal terhadap hasil produksi tanaman. Penggunaan benih unggul bersertifikat berpengaruh terhadap hasil produksi tanaman yang semakin baik dan sebaliknya penggunaan benih tidak unggul dan tidak berlabel sertifikat maka hasil produksi tanaman tidak baik, ditandai dengan kualitas dan jumlah rendah dikarenakan rentan terhadap hama dan penyakit tanaman. 


\section{Pengaruh Harga Pupuk}

Hasil perhitungan uji t pada harga pupuk $\left(\mathrm{X}_{2}\right)$ terhadap penerimaan hasil usahatani padi di tingkat petani $(\mathrm{Y})$ pada musim tanam pertama diperoleh bahwa nilai $\mathrm{t}$ hitung $=1,371 \leq \mathrm{t}$ tabel $=$ 2,015 atau nilai significant $\mathrm{t}$ hitung $=0,173 \geq 0,05$ dengan tingkat kepercayaan $95 \%(\alpha=0,05)$ menunjukkan nonsiqnificant, maka $\mathrm{H}_{0}$ diterima dan $\mathrm{H}_{1}$ ditolak. Hal ini berarti bahwa variabel harga pupuk $\left(\mathrm{X}_{2}\right)$ secara individu (parsial) tidak berpengaruh nyata terhadap penerimaan usahatani padi di tingkat petani (Y) dengan tingkat kepercayaan $95 \%$ pada musim tanam pertama. Nilai koefisien regresi variabel harga pupuk $\left(\mathrm{X}_{2}\right)$ menunjukkan besarnya elastisitas penggunaan harga pupuk terhadap penerimaan usahatani padi di tingkat petani $(\mathrm{Y})$ sebesar 0,068 pada musim tanam pertama, artinya penambahan variabel bebas harga pupuk $\left(\mathrm{X}_{2}\right)$ sebesar 1 (satu) persen maka penerimaan usahatani padi di tingkat petani (Y) turun sebesar 0,068 persen.

Hasil perhitungan uji t pada harga pupuk $\left(\mathrm{X}_{2}\right)$ terhadap penerimaan musim tanam kedua diperoleh nilai $\mathrm{t}$ hitung $=-0,333 \leq \mathrm{t}$ tabel $=$ 2,015 atau nilai significant $\mathrm{t}$ hitung $=0,739 \geq$ 0,05 dengan tingkat kepercayaan $95 \%(\alpha=$ $0,05)$ menunjukkan nonsiqnificant, maka $\mathrm{H}_{0}$ diterima dan $\mathrm{H}_{1}$ ditolak. Hal ini berarti bahwa variabel harga pupuk $\left(\mathrm{X}_{2}\right)$ secara individu (parsial) tidak berpengaruh nyata terhadap penerimaan usahatani padi di tingkat petani (Y) dengan tingkat kepercayaan $95 \%$ pada musim tanam kedua. Nilai koefisien regresi variabel harga pupuk $\left(\mathrm{X}_{2}\right)$ menunjukkan besarnya elastisitas penggunaan harga pupuk terhadap penerimaan usahatani padi di tingkat petani (Y) pada musim tanam kedua sebesar $-0,035$, artinya penambahan variabel bebas harga pupuk $\left(\mathrm{X}_{2}\right)$ sebesar satu persen maka penerimaan usahatani padi di tingkat petani $(\mathrm{Y})$ turun sebesar 0,035 persen.

Pupuk yang tidak memberikan pengaruh terhadap penerimaan hasil usahatani padi pada musim tanam pertama dan musim tanam kedua sesuai dengan penggunaan yang biasa atau sering responden petani padi gunakan, yaitu jenis pupuk yang digunakan oleh responden petani padi sebanyak 33 orang $(27,50 \%)$ menggunakan pupuk anorganik dan organik, sebanyak 86 orang (71,67\%) menggunakan pupuk anorganik saja, dan yang menggunakan hanya pupuk organik saja sebanyak 1 (satu) orang. Kondisi ini menunjukkan bahwa kurangnya aplikasi pupuk organik menyebabkan ketidakseimbangan pupuk di dalam tanah.
Kekurangan bahan organik di dalam tanah akan menyebabkan berkurangnya kandungan air tanah, tanah tidak gembur, ketersediaan unsur hara sedikit karena di musim kemarau akan diikat kuat oleh partikel tanah sehingga tidak cukup tersedia. Pengunaan pupuk anorganik yang terus-menerus, sejak program revolusi hijau sampai sekarang menyebabkan residu (sisa) yang diikat kuat oleh partikel tanah dan tidak tersedia cukup di dalam tanah untuk akar tanaman. Kekurangan bahan organik di dalam tanah dapat menyebabkan pupuk mudah terbawa air irigasi karena banjir atau air melimpah di lahan padi pada musim hujan dan pada musim kemarau menyebabkan tanah kering, pecah-pecah, tidak lembab, dan tidak gembur sehingga pupuk yang diberikan menguap dan tidak larut dalam air tanah sehingga pupuk tidak cukup tersedia untuk akar tanaman (Hardjowigeno, 2007).

Aplikasi pemupukan dilakukan oleh seluruh petani padi pada pagi atau sore hari, tetapi jika tenaga kerja berubah (karena derep, berkurangnya petani padi karena menjadi buruh bangunan, menunggu tenaga kerja yang sudah biasanya menyebabkan waktu habis hanya untuk berbincang sehingga waktu pemupukan akan mundur dari jadwal yang seharusnya. Kondisi ini dapat menyebabkan pertumbuhan tanaman padi terganggu sehingga berpengaruh terhadap hasil padi. Hal ini dapat disebabkan pula adanya efek residu (sisa) dari pemupukan pada musim tanam sebelumnya sehingga kelebihan pupuk dalam tanah dan pemupukan yang tidak berimbang memberikan dampak negatif terhadap hasil (Hardjowigeno, 2007).

Berapapun jumlah pupuk yang digunakan dalam range (rentang) petani maka tidak akan menunjukkan pengaruh nyata terhadap penerimaan usahatani padi, karena perbedaan penerimaan yang nyata dapat ditentukan faktor lainnya yang tidak dimasukkan ke dalam model ini, seperti : (1) cara pemberian pupuk tidak tepat waktu, (2) pemupukan tidak berimbang, dan (3) teknik pemupukan tidak sesuai anjuran sehingga banyak pupuk yang tidak dapat diserap oleh akar tanaman (Hardjowigeno, 2007). Soekartawi, dkk. (1986) meyebutkan bahwa pupuk yang digunakan menjadi faktor penentu terhadap hasil komoditas pertanian.

\section{Pengaruh Harga Pestisida}

Hasil perhitungan uji t pada harga pestisida $\left(\mathrm{X}_{3}\right)$ terhadap penerimaan usahatani padi di tingkat petani (Y) pada musim tanam 
pertama menunjukkan bahwa nilai t hitung = $0,825 \leq \mathrm{t}$ tabel $=2,015$ atau nilai significant $\mathrm{t}$ hitung $=0,411 \geq 0,05$ dengan tingkat kepercayaan $95 \%(\alpha=0,05)$ adalah nonsiqnificant, maka $\mathrm{H}_{0}$ diterima dan $\mathrm{H}_{1}$ ditolak. Hal ini berarti bahwa variabel harga pestisida $\left(\mathrm{X}_{3}\right)$ secara individu (parsial) tidak berpengaruh nyata terhadap penerimaan usahatani petani padi (Y) dengan tingkat kepercayaan $95 \%$ pada musim tanam pertama. Nilai koefisien regresi sebesar $-0,028$, berarti penambahan harga pestisida $\left(\mathrm{X}_{3}\right)$ sebesar 1 (satu) persen maka penerimaan usahatani padi di tingkat petani (Y) akan menurun sebesar 0,028 persen pada musim tanam pertama dengan anggapan bahwa faktor penerimaan lainnya tetap (variabel bebas lainnya tetap).

Responden petani padi biasanya menggunakan pestisida, yaitu anorganik dan organik sebanyak 5 orang $(4,17 \%)$, anorganik saja sebanyak 112 orang $(93,33 \%)$, organik saja sebanyak 2 orang $(1,67 \%)$, dan tidak pakai keduanya sebanyak 1 orang $(0,83 \%)$. Hal ini berarti sebagian besar petani responden kurang lebih 112 orang $(93,33 \%)$ menggunakan bahan anorganik saja dan tidak diperhatikan pada waktu penyemprotan musim penghujan maka dibutuhkan jenis pestisida yang mengandung zat perekat agar dapat menempel kuat pada bagian tanaman yang disemprot karena kandungan air tinggi atau kelembaban udara tinggi sehingga zat pestisida akan mudah terlarut dengan uap air atau mengalir terbawa oleh air irigasi sehingga jika tidak ada perekat maka mudah hilangnya.

Waktu penyemprotan yang biasa dilakukan responden petani pada pagi atau sore hari berjumlah 120 orang (100\%), tetapi jika pekerjaannya merasa tanggung maka penyemprotan dilakukan lewat pupuk, pekerja telat datang untuk menyemprot, dan kemauan tenaga kerja penyemprotnya. Latar belakang tenaga kerjanya sangat menentukan, seperti pendidikan, pengetahuan, dan pengalaman. Siahaan (1998) menyatakan bahwa faktorfaktor yang mempengaruhi petani dalam mengadopsi metode dan pengendalian hama terpadu adalah (1) karakter sosial ekonomi seperti pendidikan, (2) pembentukan persepsi seperti pengalaman, (3) karakteristik inovasi, seperti sifat keuntungan, komplektibilitas, dan observabilitas, serta (3) komunikasi antar petani dan instansi terkait.

Pada musim tanam kedua menunjukkan bahwa nilai $\mathrm{t}$ hitung $=6,523 \geq \mathrm{t}$ tabel $=2,015$ atau nilai significant $\mathrm{t}$ hitung $=0,00 \leq 0,05$ dengan tingkat kepercayaan 95\% $(\alpha=0,05)$ adalah siqnificant, maka $\mathrm{H}_{0}$ ditolak dan $\mathrm{H}_{1}$ diterima. Hal ini berarti bahwa variabel harga pestisida $\left(\mathrm{X}_{3}\right)$ secara individu (parsial) sangat berpengaruh nyata terhadap penerimaan usahatani padi di tingkat petani (Y) dengan tingkat kepercayaan $95 \%$ pada musim tanam kedua. Nilai koefisien regresi sebesar 0,398, berarti penambahan harga pestisida $\left(\mathrm{X}_{3}\right)$ sebesar 1 (satu) persen maka penerimaan usahatani padi di tingkat petani (Y) akan meningkat sebesar 0,398 persen pada musim tanam kedua dengan anggapan bahwa faktor penerimaan lainnya tetap (variabel bebas lainnya tetap). Soekartawi et al., (1986) menyatakan bahwa pestisida berpengaruh nyata terhadap hasil produksi komoditas pertanian, sehingga ia dibutuhkan tanaman dalam pertumbuhannya untuk mencegah serta membasmi hama dan penyakit tanaman yang mengganggu.

\section{Pengaruh Upah Tenaga Kerja}

Hasil perhitungan uji t pada upah tenaga kerja $\left(\mathrm{X}_{4}\right)$ terhadap penerimaan usahatani padi di tingkat petani (Y) pada musim tanam pertama menunjukkan bahwa nilai t hitung = $21,662 \geq \mathrm{t}$ tabel $=2,015$ atau nilai significant $\mathrm{t}$ hitung $=0,000 \leq 0,05$ dengan tingkat kepercayaan $95 \%(\alpha=0,05)$ adalah siqnificant, maka $\mathrm{H}_{0}$ ditolak dan $\mathrm{H}_{1}$ diterima. Hal ini berarti bahwa variabel upah tenaga kerja $\left(\mathrm{X}_{4}\right)$ secara individu (parsial) sangat berpengaruh nyata terhadap penerimaan usahatani padi di tingkat petani (Y) dengan tingkat kepercayaan 95\% pada musim tanam pertama. Nilai koefisien regresi sebesar 0,709 , berarti penambahan upah tenaga kerja $\left(\mathrm{X}_{4}\right)$ sebesar satu persen maka penerimaan usahatani padi di tingkat petani (Y) akan meningkat sebesar 0,709 persen pada musim tanam pertama dengan anggapan bahwa faktor penerimaan lainnya tetap (variabel bebas lainnya tetap). Hasil perhitungan uji t pada upah tenaga kerja $\left(\mathrm{X}_{4}\right)$ terhadap penerimaan usahatani padi di tingkat petani (Y) pada musim tanam kedua menunjukkan bahwa nilai thitung $=2,265 \geq \mathrm{t}$ tabel $=2,015$ atau nilai significant $\mathrm{t}$ hitung $=$ $0,025 \leq 0,05$ dengan tingkat kepercayaan $95 \%(\alpha$ $=0,05)$ adalah siqnificant, maka $\mathrm{H}_{0}$ ditolak dan $\mathrm{H}_{1}$ diterima. Hal ini berarti bahwa variabel upah tenaga kerja $\left(\mathrm{X}_{4}\right)$ secara individu (parsial) sangat berpengaruh nyata terhadap penerimaan usahatani padi di tingkat petani $(\mathrm{Y})$ dengan tingkat kepercayaan $95 \%$ pada musim tanam kedua. Nilai 
koefisien regresi sebesar 0,330 , berarti penambahan upah tenaga kerja $\left(\mathrm{X}_{4}\right)$ sebesar 1 (satu) persen maka penerimaan usahatani padi di tingkat petani $(\mathrm{Y})$ akan meningkat sebesar 0,330 persen pada musim tanam kedua dengan anggapan bahwa faktor penerimaan lainnya tetap (variabel bebas lainnya tetap).

Umur petani mempunyai peranan penting dalam proses keberhasilan usahatani padi. Usia semakin lanjut, tingkat produktivitas petani semakin berkurang. Kondisi kelompok umur responden masih didominasi pada kelompok umur 36-45 tahun sebanyak 35 orang $(29,17 \%)$, kelompok umur 46-55 tahun sebanyak 41 orang $(34,17 \%)$. Kedua kelompok umur ini masih dikatakan sebagai kelompok umur produktif berkisar 36-55 tahun sebanyak 76 orang $(63,34 \%)$. Kelompok umur yang terkecil adalah kelompok umur 25-35 tahun sebanyak 13 orang $(10,83 \%)$ dan kenyataan pada umur responden petani padi lebih dari 56 tahun sebanyak 31 orang $(25,83 \%)$ masih melakukan usahatani padi walaupun tergolong kelompok umur tidak produktif.

Hal ini ditunjukkan dengan regenerasi di kalangan petani sendiri sangat lambat mengingat bahwa anggapan anak-anak mudanya bahwa pertanian atau tanam padi tidak menjanjikan sehingga cenderung untuk bekerja di kota atau di luar bidang pertanian. Soekartawi et al. (1986) menegaskan bahwa tenaga kerja dengan upah yang diberikan sangat berpengaruh pada produksi hasil, dan tenaga kerja terampil akan mudah menerapkan teknologi tepat guna sesuai anjuran. Siahaan (1998) menegaskan bahwa faktor yang mempengaruhi adopsi petani terhadap metoda Pengendalian Hama Terpadu (PHT) adalah tingkat pendidikan, pengalaman, inovasi, dan komunikasi antar petani dan antar pembuat pembaharu yaitu Dinas Pertanian.

Lebih lanjut, Rammadhan (2013) menegaskan bahwa keputusan petani sangat menentukan dalam penggunaan input produksi (termasuk dalam aplikasi benih unggul bersertifikat). Mereka mau membeli benih bersertifikat karena didasari oleh keinginan memperoleh produktivitas padi tinggi yang didorong oleh perolehan informasi yang tepat sehingga menambah pemahaman petani terhadap benih. Pada kenyataan di lapangan, besaran tingkat upah tenaga kerja sangat tergantung kepada profesional atau tidaknya seseorang dalam bidangnya. Keahlian spesifik menjadi parameter baru dalam tingkat upah.

\section{Pengaruh Sewa Lahan}

Hasil perhitungan uji t pada sewa lahan $\left(\mathrm{X}_{5}\right)$ terhadap penerimaan usahatani padi di tingkat petani (Y) pada musim tanam pertama menujukkan bahwa nilai thitung $=4,633 \geq \mathrm{t}$ tabel $=2,015$ atau nilai significant $\mathrm{t}$ hitung $=$ $0,000 \leq 0,05$ dengan tingkat kepercayaan $95 \%$ $(\alpha=0,05)$ menunjukkan siqnificant, maka $\mathrm{H}_{0}$ ditolak dan $\mathrm{H}_{1}$ diterima. Hal ini berarti bahwa variabel sewa lahan $\left(\mathrm{X}_{5}\right)$ secara individu (parsial) tidak berpengaruh nyata terhadap penerimaan usahatani padi di tingkat petani (Y) dengan tingkat kepercayaan $95 \%$ pada musim tanam pertama. Nilai koefisien regresi variabel sewa lahan $\left(\mathrm{X}_{5}\right)$ menunjukkan besarnya elastisitas penggunaan sewa lahan terhadap penerimaan usahatani padi di tingkat petani $(\mathrm{Y})$ pada musim tanam pertama sebesar 0,217 , artinya dengan menambahkan variabel bebas seperti sewa lahan $\left(\mathrm{X}_{5}\right)$ sebesar 1 (satu) persen maka penerimaan usahatani petani padi (Y) akan naik sebesar 0,217 persen.

Musim tanam kedua dari hasil perhitungan uji t pada sewa lahan $\left(\mathrm{X}_{5}\right)$ terhadap penerimaan usaha tani padi di tingkat petani $(\mathrm{Y})$ terlihat bahwa nilai $\mathrm{t}$ hitung $=0,292 \leq \mathrm{t}$ tabel $=$ 2,015 atau nilai significant $\mathrm{t}$ hitung $=0,771 \geq$ 0,05 dengan tingkat kepercayaan $95 \%(\alpha=$ $0,05)$ menunjukkan nonsiqnificant, maka $\mathrm{H}_{0}$ diterima dan $\mathrm{H}_{1}$ ditolak. Hal ini berarti bahwa variabel sewa lahan $\left(\mathrm{X}_{5}\right)$ secara individu (parsial) tidak berpengaruh nyata terhadap penerimaan usahatani padi di tingkat petani $(\mathrm{Y})$ dengan tingkat kepercayaan 95\% pada musim tanam kedua. Nilai koefisien regresi variabel sewa lahan $\left(\mathrm{X}_{5}\right)$ menunjukkan besarnya elastisitas penggunaan sewa lahan terhadap penerimaan usahatani padi di tingkat petani (Y) pada musim tanam kedua sebesar 0,037 , artinya dengan menambahkan variabel bebas sewa lahan $\left(\mathrm{X}_{5}\right)$ sebesar 1 (satu) persen maka penerimaan usahatani petani padi $(\mathrm{Y})$ turun sebesar 0,037 persen.

Soekartawi, et al. (1986) dan Yelni (1999) menegaskan, kondisi lahan sangat berpengaruh terhadap produksi hasil pertanian atau usahatani padi, baik dilihat dari luasan lahan, tingkat kesuburan tanahnya, dan penggunaannya seperti lahan sawah, tegalan, kebun, dan lain-lain sehingga berpengaruh pada harga sewa lahan tersebut. Semakin tinggi tingkat produktivitas lahan terhadap usahatani maka semakin tinggi pula sewa lahannya. 


\section{KESIMPULAN}

Berdasakan hasil analisis regresi linier berganda pada penelitian ini maka dihasilkan secara serempak faktor harga benih, harga pupuk, harga pestisida, upah tenaga kerja, dan sewa lahan berpengaruh nyata terhadap penerimaan hasil padi di tingkat petani pada musim tanam pertama dan kedua; faktor harga benih, upah tenaga kerja, dan sewa lahan secara parsial berpengaruh nyata pada penerimaan hasil padi di tingkat petani pada musim tanam pertama; dan faktor harga benih, harga pestisida, dan upah tenaga kerja secara parsial berpengaruh nyata terhadap penerimaan hasil padi di tingkat petani pada musim tanam kedua.

Perlunya perhatian dari berbagai pihak, seperti instansi terkait, penyuluh di lapangan, dan petani padi sendiri pada faktor-faktor yang berkaitan dengan produksi padi agar dapat memberikan pengaruh yang signifikan terhadap penerimaan hasil padi di tingkat petani Kabupaten Indramayu.

\section{DAFTAR PUSTAKA}

Arikunto, S. 2006. Manajemen Penelitian. Rineka Cipta. Jakarta.

Dinas Pertanian dan Peternakan. 2012. Laporan Tahunan. Kabupaten Indramayu.

Gomez, K.A., dan Gomez, A.A. 1995. Prosedur Statistik untuk Penelitian Pertanian. Edisi Kedua. Penerbit UI Press. Jakarta.

Hardjowigeno, S. 2007. Ilmu Tanah. Cet.Keenam. CV. Akademika Pressindo. Jakarta.

Nazir, M. 1983. Metode Penelitian. Cetakan Ketiga. Ghalia Indonesia. Jakarta.
Ramadhan, F. 2013. Faktor-Faktor yang Mempengaruhi Keputusan Pembelian Petani dalam Memilih Benih Padi Bersertifikart PT SHS (Sang Hyang Seri) di Kabupaten Bogor. Skripsi. Departemen Agribisnis Fakultas Ekonomi Manajemen IPB.

Siahaan, T.L. 1998. Faktor-Faktor yang Mempengaruhi Petani dalam Mengadopsi Metode Pengendalian Hama Terpadu (Kasus Kelompok Tani di Desa Sibentang, Kecamatan Leuwiliang, Kabuapten Bogor Provinsi Jawa Barat). Skripsi. Jurusan Ilmu-Ilmu Sosial Ekonomi Pertanian IPB.

Soekartawi, A. S., J. L. Dillon, dan J. B. Hardaker. 1986. Ilmu Usahatani dan Penelitian Untuk Pengembangan Petani Kecil. Cetakan Ketiga. Penerbit Universitas Indonesia. Salemba. Jakarta.

Suherman, A. 2013. Kehidupan Petani Pasca Konversi Lahan Sawah Beririgasi di Kabupaten Indramayu. Disertasi Program Doktor Ilmu Pertanian. Unpad.

Supranto. 1995. Ekonometrika. Fakultas Ekonomi Universitas Indonesia. Jakarta.

Yelni. 1999. Faktor yang Mempengaruhi Produksi dan Pendapatan Usahatani Padi Sawah Pada Jaringan Irigasi Teknis dan Irigasi Sederhana (Studi Kasus di Desa Tingga Jaya, Kecamatan Jatilawang dan Desa Losarai Kecamatan Rawlo Kabupaten Banyumas Jawa Tengah). Skripsi. Jurusan Ilmu-Ilmu Sosial Ekonomi Pertanian Fakultas Pertanian IPB. 